\title{
Articles
}

\section{Information Literacy for Teaching and Learning: A Course for Teacher Practitioners}

\author{
By Sara Bushong and Colleen Buff
}

\begin{abstract}
Teachers are faced not only with standards-based instructional design daily, but with the shortage of certified school library media specialists within their districts.

Information Literacy for Teaching and Learning, a graduate level course, was created, in

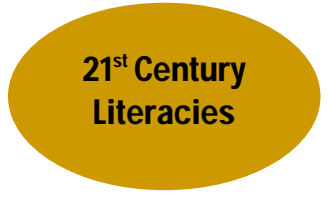
part, to empower teachers with the knowledge, skills and abilities to embed information literacy within classroom learning experiences. In addition, the skills mastered and activities explored in this course logically transfer to research projects assigned in future graduate courses.
\end{abstract}

\section{Introduction}

Most children in today's PreK-12 learning environment have grown up with the Internet and a mind-boggling amount of information available to them via their computers. Even so, this does not make them computer or information literate. These are skills that students need time to learn, practice, and develop throughout all levels of their education. Unfortunately, teachers are in the position of having to learn these skills as well, since many of them did not grow up in a dynamic, electronic information age. Because being information literate does not reside in any one discipline, there is often no one particular person in the school setting to whom this responsibility should fall. Rather, these are skills that cross boundaries and therefore whether or not these competencies are part of the standards-based education system should be a concern to all educators.

This is a case study that explains one attempt to provide graduate-level instruction to teacher practitioners interested in working independently or in collaboration with their school library media specialist to integrate the instruction of information literacy into their PreK-12 teaching.

Review of the Literature

A review of the literature reflects that at many institutions in the United States and Canada, library and information literacy instruction is embedded in the pre-service teacher preparation programs at the undergraduate level (Battle, 2007; Johnson \& O’English, 2003; Naslund, Asselin, \& Filipenko, 2005; O’Hanlon, 1988; Witt \& Dickinson, 2003). A study of one such undergraduate approach concludes that preservice teachers are not effectively learning about school library programs and information literacy pedagogy (Asselin \& Doiron, 2003). Although stand-alone courses on information literacy competencies likely exist at the graduate level, the authors were not able to identify any documented analysis of this approach in the professional literature.

\section{Rationale for Starting the Course}

The pre-service teacher education curriculum at Bowling Green State University (BGSU) is rigorous in an attempt to satisfy the National Council for Accreditation of Teacher Education (NCATE) 2008 accreditation demands and in order to prepare future teachers to incorporate a variety of academic content standards at the state and national levels into student learning experiences (Ohio, 2008). In short, there is no room in the pre-service undergraduate curriculum to offer a stand-alone course on information literacy. This is not to say that there is not a place for information literacy concepts in the

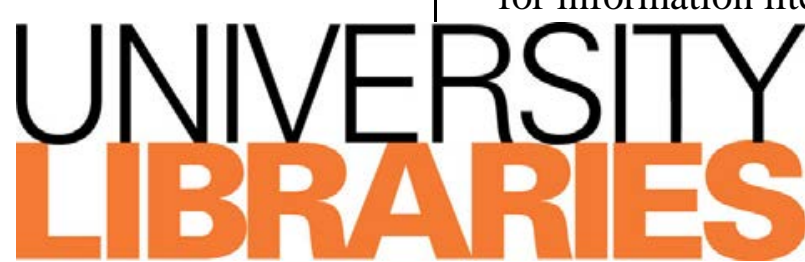

undergraduate education curriculum. In fact, information literacy experiences are strategically and systematically integrated 
throughout the undergraduate teacher preparation program at BGSU. After closely examining the undergraduate and graduate level curriculum, it was evident that there was more flexibility in the graduate curriculum to absorb a new course offering and ultimately take information literacy skills development to the next level.

Since BGSU offers a Masters in Education, it seemed the perfect place to suggest an elective, stand-alone course devoted to information literacy. The rationale was that teacher practitioners would already possess relevant classroom experience, established teaching practices and be interested in creating new research activities to enhance their teaching as well as their students' learning experiences. Additionally, with the shortage of certified school library media specialists in many school districts around the state, there was a need to empower classroom teachers with the knowledge, skills, and abilities to teach information seeking behaviors. Three to four sections of the course are offered over six weeks during the summer session. Instructors are librarians within the BGSU University Libraries system and are uniquely qualified to design and deliver course material. Instructor experience includes undergraduate degrees in education, graduate degrees in education, and successful PreK-16 teaching experience. Given the complex nature of the cooperative library system in the state of Ohio, it is critical that academic librarians with a solid understanding of each of the three systems maintain the responsibility for teaching this course. It is a full-time job keeping abreast of the changes in these cooperatives, a responsibility that would be overwhelming for an education faculty member to handle.

The course description builds upon the definition of information literacy as the ability to locate, evaluate and effectively use information resources as fundamental for student success in grades PreK-12 and beyond. The course focuses on examining and promoting lifelong

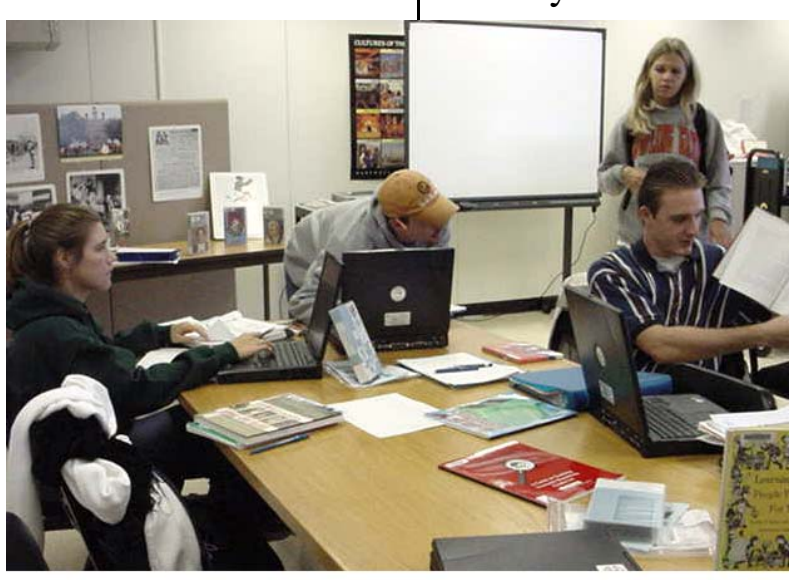

Bowling Green State University Students information literacy skills and instructional models useful when crafting effective research assignments. Students explore online, print and non-print information resources available in public, school and academic settings. Emphasis is placed on critical thinking, resource analysis, standards research (local, state and national in scope) and the ethical use of information.

Readings, skills mastered and activities explored in this course logically transfer to research projects in subsequent graduate courses and extend to real-life applications in the PreK-12 classroom.

\section{Student learning outcomes for the course include the following components:}

- Students will gain an understanding of the organizational structure of print, non-print and electronic information resources.

- Students will be able to determine the scope of an information tool during the selection process.

- Students will explore and master the intricacies of search strategies for application in any research environment.

- Students will be able to create effective learning experiences for PreK-12 students that integrate the research process into the curriculum.

\section{About the Course}

Ohio has a complex system of multiple library cooperatives that consist of three divisions: public, PreK-12, and higher education. The public library cooperative is called the Ohio Public Library Information Network (OPLIN, 2007). The PreK12 system is known as The Information Network for Ohio Schools, INFOhio (2008) and the system for higher education is known as the Ohio Library and Information Network (OhioLINK, 2008). Although there is some cooperation and resource sharing among these three entities, the mission of each is specifically geared towards the needs of their respective populations. 
The structure of the course touches upon the resources provided by each of the three statewide cooperatives, with an emphasis on resources specific to teaching students PreK-12, but the skills teachers need to be information literate as graduate students are also addressed.

From the onset, the course was designed to be practical. Each project was strategically designed in such a way that the teachers would be able to incorporate the end products in their classrooms with their students. Mechanisms have been created to share the reviewed work of the teachers with other educators throughout the state of Ohio. Feedback received over the years indicated that this sharing creates added value among the teachers because much of their graduate studies have taken a more theoretical approach. widely-used approach to teaching information and technology skills in the world." (Big6 overview, 2008) This research model is demonstrated in the course by using the example of purchasing a new automobile and includes research terminology familiar to educators. Students participate in an activity to compare and contrast additional research and information literacy models, and are challenged to consider adopting a particular model for students to use in their own classroom, thus seamlessly integrating information literacy principles into instruction. As each teacher's school environment and access to library support differs dramatically, the benefits of having an entire grade, school or even school district adopt a particular model is discussed.

For the second part of this module, students work intensively with the Ohio Academic Content

The course begins with an indepth overview of the structure of the information environment, an examination of the multiple definitions of information literacy, and the concept of transferable research skills from one online environment to the next. For most students it is the first time they have been asked to

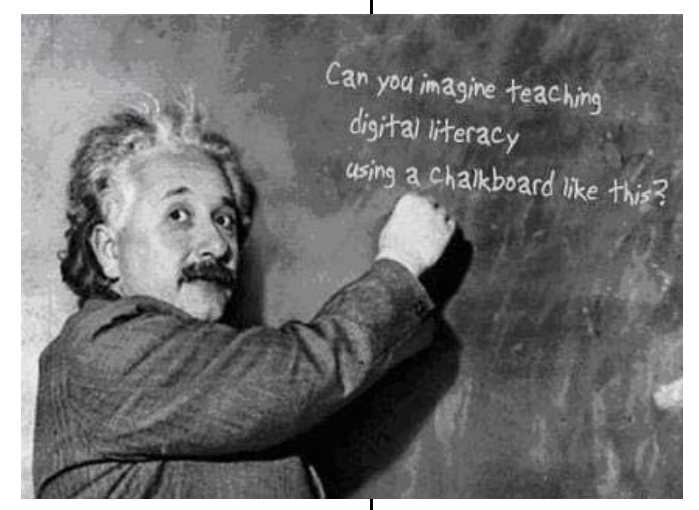
Standards (Ohio, 2008). Through a hands-on, small group activity, students look for the presence of information literacy competencies in the academic content areas, technology standards and library guidelines, and then sort them strategically within the Big6 $6^{\mathrm{TM}}$ categories. Areas of overlap as well as deficiencies are identified and students examine approaches consider information retrieval in the context of the teaching and learning environment. In addition to understanding how information is organized on a large scale, students are introduced to general research concepts that are utilized in most online environments such as how to conduct keyword searches, when to use Boolean operators, and what truncation searches accomplish. Students practice the use of these search skills at length and are asked to intentionally use the skills throughout the course.

The second module in the course includes an examination of the various information literacy models and the different standards expected to be incorporated into the projects throughout the course. In the first part of this module, the Big6 $6^{\mathrm{TM}}$ research model, created by Robert Berkowitz and Mike Eisenberg, is explored. According to their website, "Big6 is the most widely known and to addressing information literacy in interdisciplinary ways. Students are also introduced to the American Association of School Librarian's Standards for the $21^{\text {st }}$ Century Learner (AASL, 2008), the Nine Information Literacy Standards for Student Learning (AASL, 1998) and the Information Literacy Competency Standards for Higher Education from the Association of College and Research Libraries (ACRL, 2008).

By the third module, the final project is unveiled. At the end of the course, students are expected to build a WebQuest, which is an inquiry-based lesson in which most of the content utilizes online resources (Dodge, 2007.) This approach was popularized by Bernie Dodge at San Diego State University, and is utilized because of the model's close alignment with information literacy competencies and research seeking behaviors. The rationale for using this model as a final project is 
that it is an excellent mechanism for students to synthesize all of the resources they are exposed to in the course and to apply them to a real world learning experience for their students. Students in the course have significant latitude in how to construct their WebQuest. Because most of the students have little, if any, experience with web authoring tools such as Dreamweaver or Microsoft FrontPage, Microsoft PowerPoint was chosen as the application of choice because it is familiar to most students as well as usually supported by most school systems. A template was constructed in Microsoft PowerPoint which includes the primary components and framework for their WebQuest: Introduction, Task, Resources, Process, Evaluation, and Conclusion. In addition, the typical structure of a WebQuest has been slightly modified to include the components of Standards, Citations, and Teacher Notes to the framework.

In the next module, students are oriented to the INFOhio resources which include approximately a dozen different databases, most of which are available in each school district within the state of Ohio as well as remotely. Resources are available for a variety of content areas and all grade levels. Although all teachers theoretically have access to the network in the state of Ohio via their school districts, for many of them, this is the first time they have either been exposed to these resources or have devoted time to exploring the contents and classroom applicability of the resources. A tenminute learning activity is assigned at this point. In this exercise students create a mini-tutorial that will train their students and/or colleagues in one of the INFOhio databases to answer a specific research question. All tutorials are expected to include the following elements: the database name, grade level, topic/subject area, essential question, applicable academic content standards, search steps, additional comments or helpful hints about how the database works. Students are required to develop the essential research question in this tutorial assignment in such a way that it fits in with the final WebQuest project. Examples of the learning activities are housed on the Educator page from the INFOhio website (INFOhio teacher, 2008).
Because not all PreK-12 students have computer access at home, and because schools are not open during evening hours, instructors are intentional about including the statewide public library consortium, the Ohio Public Library Information Network (2007.) Any resident of Ohio may obtain a library card that enables users to access many of the online sources available through this consortium from remote locations. While there is some overlap in the online offerings between OPLIN and INFOhio, there are unique offerings as well. Students in the course are given activities and time to explore the wealth of resources in OPLIN, and they are encouraged to incorporate these findings into their final WebQuests.

The module on Effective Internet Searching changes frequently due to the volatile nature of the Internet. Students learn about search engine math and logic as well as the different types of searching tools such as search engines, directories, and meta search engines. In addition to exploring the advanced search features of Google, students are provided the opportunity to learn about, utilize and compare functionalities between other search engines such as Ask.com and Dogpile.com.

In aligning the course structure with the tenants of information literacy competencies, a module is included on the ethical and responsible use of information and explores the topics of plagiarism and copyright infringement. This is an increasingly popular topic because instances of plagiarism have been and continue to be on the rise (McCabe, 1999). Teachers struggle with methods to detect and prevent acts of academic dishonesty. This class provides concrete strategies with the added benefit of meeting regularly with a group of professionals with whom they can exchange ideas and strategies to combat this problem. The notion that teaching ethical use of information is the responsibility of the English composition teacher at the high school level is dispelled. Everyone is encouraged to embrace this problem as well as model ethical use of information and multimedia in their teaching practices. 
As graduate students, teacher practitioners struggle with utilizing academic resources to search for research-based articles and monographs required for courses taken prior to this one and for upcoming classes. An academic resources module was created to address these concerns as students had repeatedly commented that this course was needed earlier in their program of study. Subject, keyword and title searching of books and multimedia resources are introduced through the BGSU (2008) online catalog and the central OhioLINK (OhioLINK library, 2008) catalog during Part One of this module. Part Two introduces students to the wealth of resources available through research databases purchased locally and cooperatively within OhioLINK. Students are

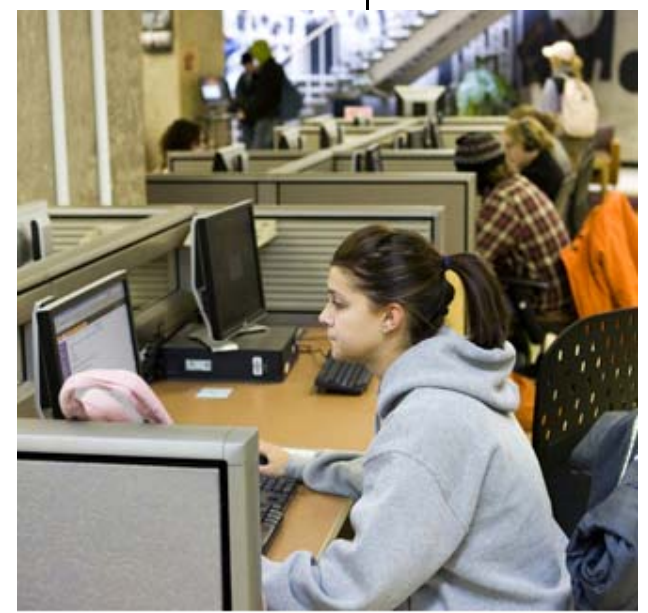

Bowling Green State University Library
Recently, the course was adapted to include practical uses of Internet 2.0 technologies as a mechanism to foster student-to-student and student-to-teacher collaboration by utilizing social networking tools for educational purposes. This module provides an overview of the different types of Internet 2.0 technologies while offering hands-on practice with contributing to a class wiki and class blog. Students were asked to read a series of articles on social networking and the instructional design effects of Internet 2.0 technologies. The next step was to respond to the readings via a discussion board prompt within Blackboard, the campus course management system. Responses indicated that in-service teachers recognize the need to stay abreast of the new technologies and to engage their students in learning activities to prepare them for the challenges and opportunities presented in online environments.

resources available through Internet browsers, and this becomes another opportunity to draw attention to the differences between the two and the benefits of the breadth of scholarship available through the fee-based databases. ERIC and Education

Research Complete are demonstrated and students participate in activities designed to increase their content knowledge and search strategies. During the final part of this module, students practice citing resources (print, electronic and Internet) using the APA citation style. This is particularly useful within this course for the citation section of the WebQuest as well as in future classes that require research papers.

Final projects are presented to the entire class during the last day of the course. The teachers enjoy sharing their work with their colleagues, and the instructors have an opportunity to view the overall functionality, design and subject content of the WebQuest as they are projected for all to review. Students are encouraged to use the projects with students in the fall, and the most accomplished WebQuests are posted on the Information Literacy WebQuests website (WebQuests, 2008).

\section{Results and Further Research}

The work products generated by the graduate students in this course are far reaching. They have the opportunity to improve their personal information literacy skills while building grade and content appropriate materials to improve the information literacy skills of their students. Additionally, students are helping to connect resources with teaching and learning. A teacher's work day is hectic and all-consuming with little time left at the end of the day to explore information resources. The course Information Literacy for Teaching and Learning affords teachers the opportunity to discover new resources to enhance the classroom experience.

To view the work products of students enrolled in sections of this course, visit the following links.

- Information Literacy WebQuests http://www.bgsu.edu/colleges/library/crc/page38734.html (WebQuests, n.d.)

- 10 Minute Learning Activities http://infohio.org/Educator/LearningActivities.html (INFOhio teacher, 2008.) 
Exit surveys and informal conversations with students indicate that at the conclusion of the course there is a much greater awareness of online resources available through INFOhio, OPLIN and OhioLINK; they have begun to master the idea of transferable research strategies; and they were able to create an inquiry-based activity using a familiar software application.

Over the six years the class has been offered, patterns have emerged worth noting. While teachers' comfort level with the technology seems to have improved, many continue to be unaware of all of the educational information resources available to them through the library cooperative systems. The students consistently respond that the course allows them the space in their busy professional lives to be reflective about information and technology use in the classroom. Evaluative comments include:

- Activities were beneficial for use in my classroom

- Assignments and lessons related to classroom-very helpful!

- Very applicable to my teaching.

- Course content was meaningful and useful. Assignments were practical and reasonable.

- Very practical. We were able to adapt the projects to something we could use in the classroom.

- This course was the most effective class I have taken so far in my full year in this cohort.

- This course should be the first class. All the information would have been useful at the beginning of the program.

- This course should be taken by ALL M.Ed (Masters of Education) students.

Future research plans include a follow-up assessment with teachers who have been through the class to determine the skills most utilized from the course and how it has changed the way they teach. Multiple sections of the course have been offered since 2003, reaching over 400 teacher practitioners in the northern region of Ohio. With this data, the co-authors will be better prepared to showcase the merits of this course to other
Masters of Education programs around the state of Ohio. If universities in other regions of Ohio were to offer a similarly structured course, the potential to effect meaningful change in informationseeking skills for teachers and students could be realized.

\section{References}

AASL standards for the $21^{\text {st }}$ century learner. (2008). Retrieved June 29, 2008, from the American Association of School Librarians website: http://www.ala.org/ala/aasl/aaslproftools/learningst andards/standards.cfm

ACRL. Information literacy competency standards for higher education. (2008). Retrieved from the Association of College and Research Libraries website:

http://www.ala.org/ala/acrl/acrlstandards/informatio nliteracycompetency.cfm

American Association of School Librarians (AASL). (1998). Information power: Building partnerships for Learning. Chicago: Illinois.

Asselin, M., \& Doiron, R. (2003, October). Whither they go: An analysis of the inclusion of school library programs and services in the preparation of pre-service teachers in Canadian Universities. Behavioral \& Social Sciences Librarian, 22(1), 1932.

Battle, J. (2007, Fall). Information literacy instruction for educators and the role of school and academic libraries. Texas Library Journal, 83(3), 124-125.

The Big 6. (2008). Retrieved June 29, 2008, from the Big 6 website: http://www.big6.com/

The Big 6 - overview. (2008). Retrieved September 8, 2008, from the Big 6 website: http://www.big6.com/category/overview-of-big6-skills/

BGSU libraries catalog. (2008). Retrieved from the BGSU University Libraries website: http://maurice.bgsu.edu/search/X

Dodge, B. WebQuest.Org: home. (2007). Retrieved June 29, 2008 from the WebQuest.Org website: http://webquest.org/index.php

INFOhio teacher tools - learning activities. (2008). Retrieved June 29, 2008, from the INFOhio website: http://infohio.org/Educator/LearningActivities.html

INFOhio: the information network for Ohio schools. (2008, May 5). Retrieved June 29, 2008, from the INFOhio website: http://www.infohio.org/

Johnson, C., \& O'English, L. (2003, October). Information Literacy in Pre-Service Teacher Education: An Annotated Bibliography. Behavioral \& Social Sciences Librarian, 22(1), 129-139. Retrieved June 20, 2008, doi:10.1300/J103v22n01_09

McCabe, D. (1999, Winter). Academic dishonesty among high school students. Adolescence, 34(136), 
681. Retrieved September 7, 2008, from Academic Search Complete database.

Naslund, J., Asselin, M., \& Filipenko, M. (2005, Spring). Blueprint for collaboration: An information literacy project at the University of British Columbia. PNLA Quarterly, 69(3), 10-32.

NCATE: National Council for Accreditation of Teacher Education. (1997-2008). Retrieved June 29, 2008, from the NCATE website: http://www.ncate.org/

O'Hanlon, N. (1988, Summer). Up the down staircase: Establishing library instruction programs for teachers. $R Q$ 27: 528-34.

Ohio Academic content standards. (2008). Retrieved June 29, 2008, from the Ohio Department of Education website: http://www.ode.state.oh.us/GD/Templates/Pages/O DE/ODEPrimary.aspx?page $=2 \&$ TopicRelationID= $\underline{305}$

The Ohio public library information network (OPLIN). (2007). Retrieved June 29, 2008, from the OPLIN website: http://www.oplin.org/

OhioLINK: the Ohio library and information network. (2008). Retrieved June 29, 2008, from the OhioLINK website: http://www.ohiolink.edu/

OhioLINK library catalog. (2008). Retrieved June 29, 2008, from the OhioLINK website: http://olc1.ohiolink.edu/search/

WebQuests: Information literacy. (2008). Retrieved June 29, 2008 from the Curriculum Resource Center website: http://www.bgsu.edu/colleges/library/crc/page38734.html

Witt, S., \& Dickinson, J. (2003, October). Teaching teachers to teach: Collaborating with a university education department to teach skills in information literacy pedagogy. Behavioral \& Social Sciences Librarian, 22(1), 75-95.

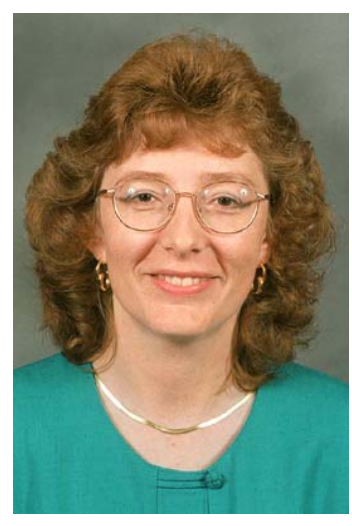

Sara Bushong is Head Librarian for the Curriculum Resource Center, and Chair, Archival Collections and Branches at Bowling Green State University (BGSU), Bowling Green, Ohio where she has worked since 2000. She was the District Elementary Librarian and Technology Curriculum Coordinator for Perrysburg Exempted Village Schools and formerly a choral music teacher in Whigham, Georgia. BGSU has a large College of Education and the SLA's publication Education Libraries is particularly relevant to undergraduate, graduate students and faculty research projects as well as to the university librarian's servicing the College. Sara's research interests include information literacy for pre-service teachers and the integration of technology into the PreK-12 curriculum. She has worked extensively with BGSU undergraduate and graduate students on independent studies and courses designed to utilize the WebQuest model to promote information literacy. Sara is involved with projects designed to "bring books to life" in area PreK-12 schools; students are actively involved in aesthetic activities designed to enhance creativity through book reviewing activities.

\section{Sara Bushong, Associate Professor}

Head Librarian, Curriculum Resource Center Chair, Archival Collections and Branches Bowling Green State University

Bowling Green, Ohio 43403

419.372.7909

sbushon@bgsu.edu

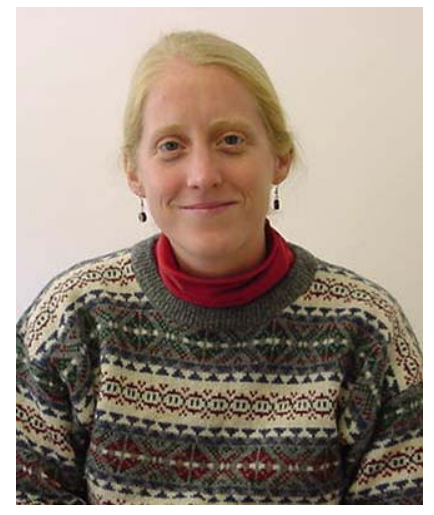

Colleen Boff is the First Year Experience Librarian at Bowling Green State University in Bowling Green, Ohio where she has worked since 1999. Prior to that, she worked briefly as a law librarian. Colleen is committed to creating a seamless transition for students as they leave the high school research environment and enter the higher education system. For the past several years, she has worked with pre-service teachers at the undergraduate level as well as teachers enrolled in the graduate program as described in this article. Colleen's professional interests include application of web 2.0 technologies in library instruction, the Millennial generation, and information literacy. Colleen also runs the Common Reading ExperienceProgram for entering first year students.

Colleen Boff, Associate Professor

First Year Experience Librarian Bowling Green State University Bowling Green, Ohio 43403 cboff@bgsu.edu 